\title{
Inversion of Electromagnetic and Magnetic Data and Self-Organizing Maps applied to Palmeirópolis Project
}

Aisengart, T.*, Geosoft Latinoamérica; Barbosa , D., Geosoft Latinoamerica; Plastow, G., Geosoft Inc; Couto Jr., M.A. Serviço Geológico do Brasil.

Copyright 2019, SBGf - Sociedade Brasileira de Geofísica

This paper was prepared for presentation during the $16^{\text {th }}$ International Congress of the Brazilian Geophysical Society held in Rio de Janeiro, Brazil, 19-22 August 2019.

Contents of this paper were reviewed by the Technical Committee of the $16^{\text {th }}$ International Congress of the Brazilian Geophysical Society and do not necessarily represent any position of the SBGf, its officers or members. Electronic reproduction or storage of any part of this paper for commercial purposes without the written consent of the Brazilian Geophysical Society is prohibited.

\begin{abstract}
In this paper we took advantage of cloud computing power, modelling techniques like VOXI inversion and machine learning (Self Organizing Maps) to map and model regional structures, local anomalies some already known (C1, C2, C3 AND C4) and also propose new targets to explore in Palmeirópolis area which is located in the state of Tocantins, Brazil. The airborne Geophysical survey was provided by Votorantim Metais and Lara do Brasil LTDA and it is composed by Versatile Transient Electromagnetic (VTEM) and Airborne Magnetic Data. To produce the results we performed MVI (Magnetization Vector Inversion) and VTEM inversion through VOXI to generate Susceptibility, Magnetization Vector and Conductivity models and Self-Organizing Maps to also characterize the magnetization domains for the entire area. With these products, we were able to analyze, integrate and better interpret the known orebodies and identify new targets.
\end{abstract}

\section{Introduction}

The Palmeirópolis Project is located in the Southern portion of Tocantins State, Brazil. Geologically and tectonically, the area is characterized by the Palmeirópolis Metavolcano-Sedimentary Sequence (PMSS), within the Central-Northern portion of the Brasilia Belt, in the Tocantins Province (Araújo et al., 1995). Its economical mineral potential is characterized by polymetallic $(\mathrm{Cu}, \mathrm{Zn}$, $\mathrm{Pb}, \mathrm{Cd}, \mathrm{Ag}$ and $\mathrm{Au}$ ) stratiform and stratabound VolcanicHosted Massive Sulfide (VHMS) deposits, discovered initially by CPRM - Geological Survey of Brazil during the 1970s. At that time, CPRM mapped four $\mathrm{Cu}, \mathrm{Zn}$ and $\mathrm{Pb}$ ore bodies: C1, C2, C3 and C4 in its mineral rights areas (Figure 1). These ore bodies occur in the Northern portion of PMSS, in association with gabbroic rocks overlaid by amphibolitic rocks originated by Middle Ocean Ridges Basalts (MORB) and restricted occurrence of iron formations intercalated with cherts and silicic-graphitic sediments (Oliveira, 2000). The ore minerals are represented by pyrrhotite, pyrite, sphalerite, chalcopyrite and galena, in order of abundance.

The Versatile Time domain Electromagnetic (VTEM) survey used in this paper was contracted by Lara do Brasil LTDA. and Votorantim Metais and executed by
Microsurvey (Votorantim, 2008). The survey location is indicated in Figure 1 (Couto Jr. et al., 2017). The survey is $\mathrm{E}-\mathrm{W}$ oriented, with flight-lines spaced by $250 \mathrm{~m}$ (tie lines in the N-S direction, spaced by $2500 \mathrm{~m}$ ), $80 \mathrm{~km} / \mathrm{h}$ speed acquisition and $58 \mathrm{~m}$ terrain clearance for the VTEM system. The VTEM system used is characterized by a transmitter loop with an area of $531 \mathrm{~m}^{2}, 26.1 \mathrm{~m}$ diameter with 4 turns and dipolar moment of 400,000 NIA. The receiver is a concentric loop which sample the data $(\mathrm{dB} / \mathrm{dt}$ and Bfield) in the vertical direction ( $Z$ axis) with $10 \mathrm{~Hz}$ sampling frequency - Figure 2. The current waveform is trapezoid-form, with average peak value of $189.4 \mathrm{~A}, 30 \mathrm{~Hz}$ base-frequency, $7.01 \mathrm{~ms}$ pulse-width and the data were sampled by 25 channels during the turning-off ramp, between 120-7828 $\mu$ s (Votorantim, 2008).

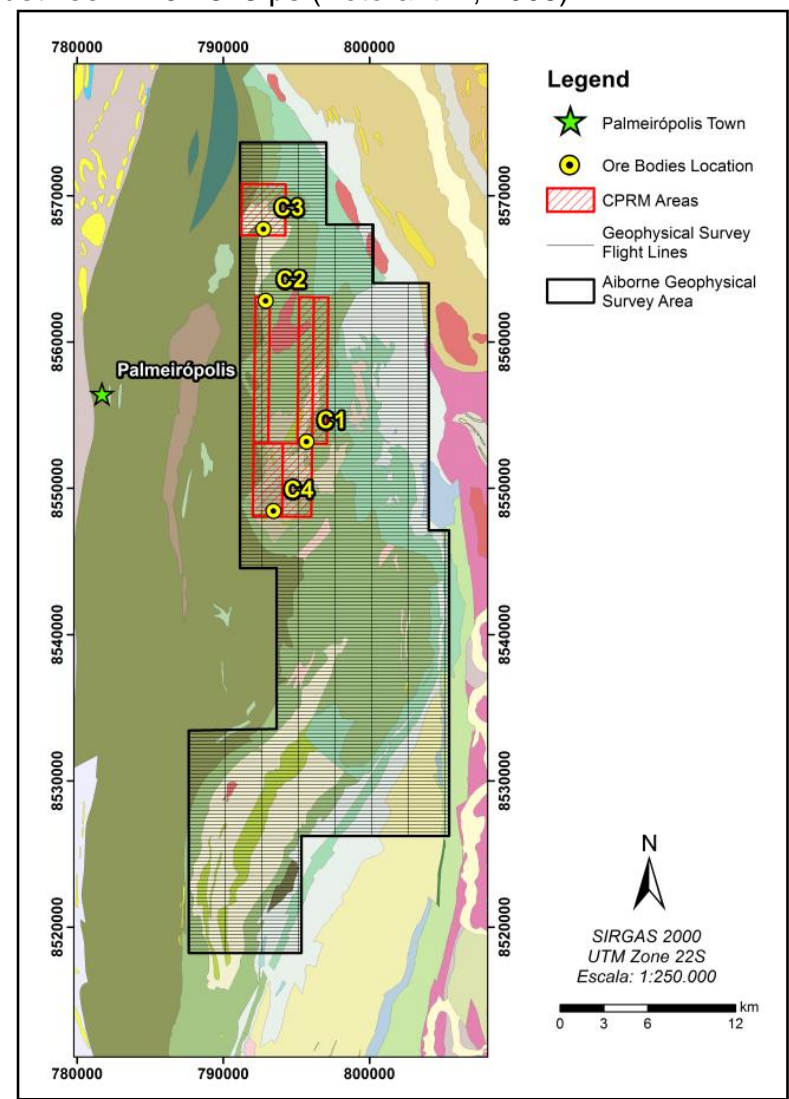

Figure 1 - Study area with C1, C2, C3 and C4 ore bodies, VTEM survey (black polygon) and CPRM mineral rights areas (red polygons).

\section{Method}

The Magnetization Vector Inversion - MVI (Ellis et al, 2012) is an inversion technique that has been recently incorporated to the normal workflow applied to magnetic 
data as it provides a much better model to represent the geological environment, considering the complex nature of the magnetic field.

Until quite recently, the physical property used to describe magnetic materials in the earth, particularly for inversion, was the susceptibility that is related to Magnetization:

$$
\vec{M}=k \vec{H} e
$$

Therefore, the Magnetization Vector target equivalent to the Susceptibility target is a collection of magnetic dipole sources and the assumption to use susceptibility is that the magnetization vector is aligned with the inducing field direction that is the Earth's field direction.

The problem is that the complex nature of rocks involves effects like remanence, demagnetization and anisotropy that needs a more generic approach as used in VOXI-MVI:

$$
\vec{M}=\left(\vec{k}+\vec{k}_{R}\right) H_{e}=\vec{k}_{M V I} H_{e}
$$

This equation shows how the MVI susceptibility relates to magnetization vector and is based on $\vec{k}_{M V I}$, the effective susceptibility (anisotropic + remanent) and through it, we can estimate inclination and declination of this effective magnetic susceptibility for a magnetic source (Aisengart, 2015), providing a better perspective of structural parameters to map the geology in subsurface.

Self-Organizing Maps (SOM) (Carneiro et al, 2012; Cracknell \& Reading, 2014) is an unsupervised classification technique used to analyze and visualize highdimensional data, based on principles of measures of vector quantization. It is an ideal tool to analyze a dataset consisting of disparate geophysical input parameters when you are looking for relationships and trends. In this paper, we used as input the Vector cartesian components ( Vx, Vy, $\mathrm{Vz}$ ) and the cartesian coordinates $(\mathrm{X}, \mathrm{Y}, \mathrm{Z})$ to produce a $3 \mathrm{~d}$ model with domains that represent vector amplitudes and directions for a specific unit.

To further investigate the results of the airborne survey electromagnetic inversions were performed using VOXI1D TDEM. The purpose of these inversions was to recover an initial conductivity model of the subsurface for mineral exploration purposes. The method and challenges surrounding the geophysical inversion of airborne EM data has been widely discussed (Ellis, 1998). Some of these challenges include the non-uniqueness of the inversion solution space, time-consuming non-linear computations of the subsurface conductivity and its relationship with measured TDEM data, and large volumes of survey data with variable noise levels. (Ellis, 1998)

The TDEM inversion is based on fast 1D inversion method with the results interpolated in $3 D$ and is powered by Microsoft Azure cloud computing through VOXI. The input data for the inversions were the normalized VTEM $\mathrm{dB} / \mathrm{dt}$ soundings $\left(\mathrm{pV} / \mathrm{Am}^{4}\right)$ from the $\mathrm{Z}$ axis receiver coil. Additional inputs to the inversion included the acquired digital elevation model and position of the VTEM transmitter and receiver coils.

Once the VOXI inversion project was configured with the TDEM data a simple forward calculation and inversion on select lines for was performed to confirm the transmitter waveform, time channel windows, a priori information and input errors.

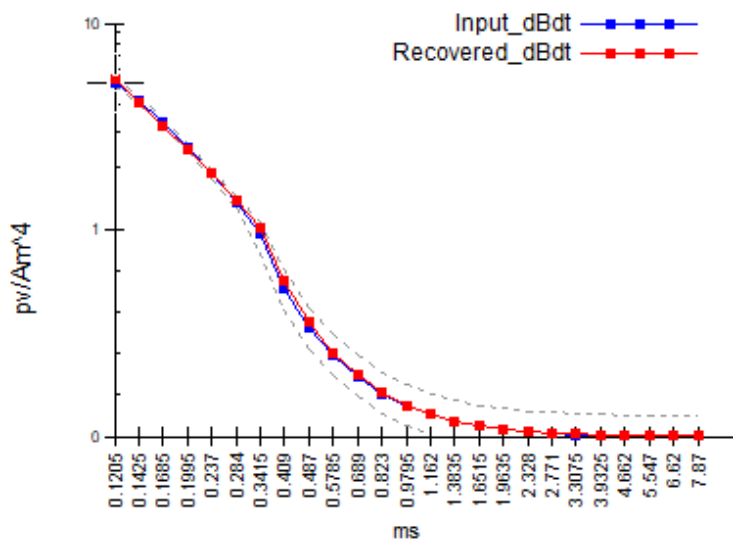

Figure 2 - Comparison of observed input $\mathrm{dB} / \mathrm{dt}$ data (blue) and recovered $\mathrm{dB} / \mathrm{dt}$ soundings (red) from initial regional scale inversion.

\section{Examples}

The airborne Geophysical survey used in this work was provided by CPRM and was performed by Votorantim Metais and Lara do Brasil LTDA being composed by Versatile Transient Electromagnetic (VTEM) and Airborne Magnetic Data.

The TMI levelled and corrected channel (Figure 3) was used as input for the MVI.

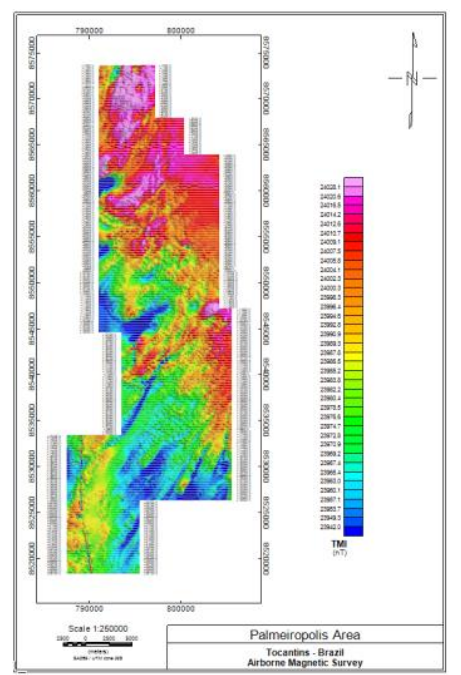

Figure 3 - TMI data from Palmeirópolis airborne survey. 
The cartesian components $(\mathrm{Vx}, \mathrm{Vy}, \mathrm{Vz})$ from the resulting $\mathrm{MVI}$ was used together with the coordinates $(X, Y, Z)$ for the SOM analysis considering $10 \%$ of the data as anomalous and 9 classes. For the regional EM inversion, a downline lateral cell spacing of $50 \mathrm{~m}$ was used, and the crossline cell spacing was $150 \mathrm{~m}$ with a total number of $1.2 \mathrm{M}$ sounding points. The regional inversion results illustrated a conductive overburden layer of varying trickiness. (Figure 4).
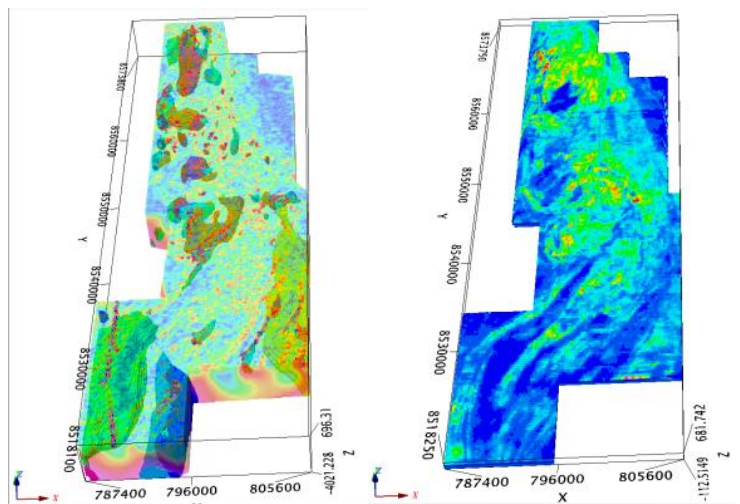

Figure 4 - Left: Amplitude of MVI and SOM anomalous classes, Right: VTEM regional inversion.

\section{Results}

The recovered $\mathrm{dB} / \mathrm{dt}$ and conductivity model was reviewed and compared with the known geology and identified $\mathrm{Cu}$, $\mathrm{Zn}$ and $\mathrm{Pb}$ ore bodies $\mathrm{C} 1-\mathrm{C} 4$ (Couto Jr., 2017) and local high-resolution inversions were performed with cell size in $X=10 \mathrm{~m}$ and $\mathrm{Y}=50 \mathrm{~m}$ for those polygons (Figure 5).

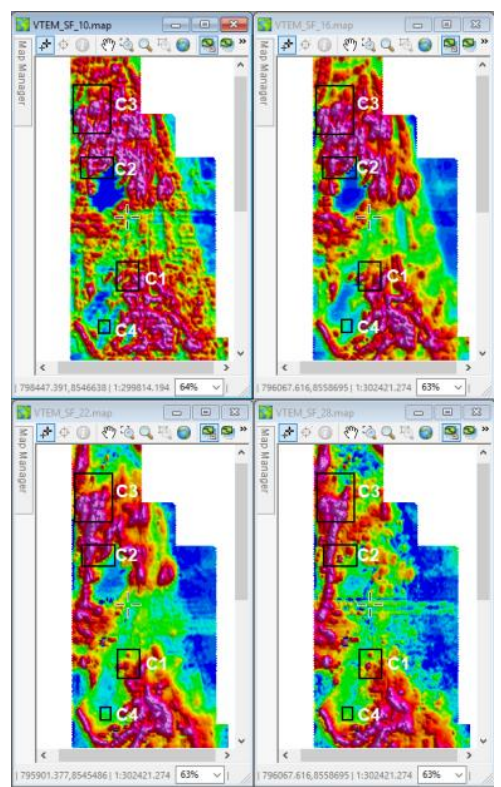

Figure 5 - Polygons used for the 4 high resolution inversions performed for $\mathrm{C} 1, \mathrm{C} 2, \mathrm{C} 3$ and $\mathrm{C} 4$ overlaid in the main late time profiles used in VOXI.
For $\mathrm{C} 1, \mathrm{C} 2$ and $\mathrm{C} 3$ the targets have a strong agreement with the CPRM report (Figure 6) and with the previous modelling of the conductors using plates (Figure 7) while the C4 model shows a result compatible with the description of disseminated pyrrotite (Couto Jr. et al, 2017) and cannot be analyzed using the same parameters as the other identified orebodies (Figure 8).

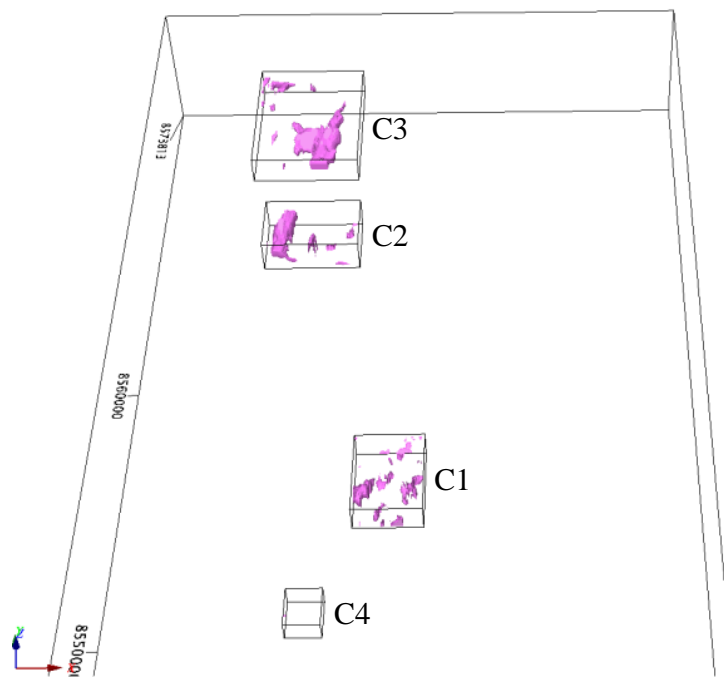

Figure 6 - High resolution inversions results for $\mathrm{C} 1, \mathrm{C} 2, \mathrm{C} 3$ and C4 clipped at $0.02 \mathrm{~S} / \mathrm{m}$ using the same color distribution for all models.

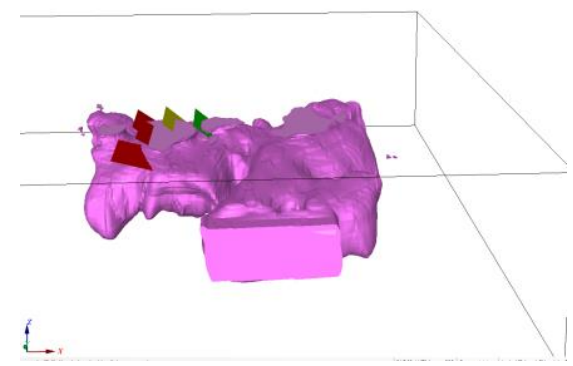

Figure $7-\mathrm{C} 3$ orebody EM high resolution inversion and plate models

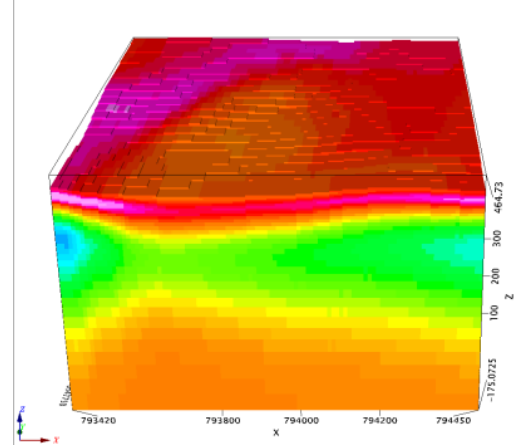

Figure 8 - High resolution inversion result for $\mathrm{C} 4$.

Integrating the SOM magnetic classes with the regional TDEM inversion, allows the identification of targets, 
including the $\mathrm{C} 1, \mathrm{C} 2$ and $\mathrm{C} 3$ orebodies already studied (Figure 9).

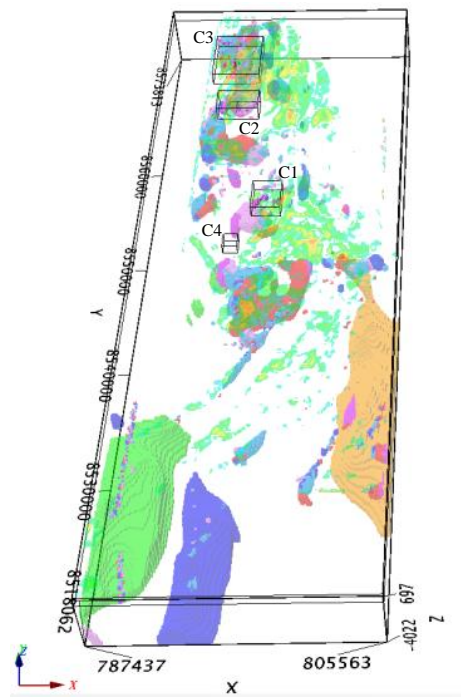

Figure 9 - SOM MVI classes, regional conductivity inversion and high-resolution inversions for orebodies C1C4 clipped at $0.02 \mathrm{~S} / \mathrm{m}$.

Encouraged with the solutions from the SOM magnetic classes and regional TDEM inversion the results highlight additional targets to be investigated. Two additional target areas were identified with the first target (T04) contained in the C4 area of interest but centered further southeast where there is a coincidence with the regional conductivity model and the same SOM classes appearing as the $\mathrm{C} 1$, $\mathrm{C} 2$ and $\mathrm{C} 3$ orebodies. The second target (T05) is located over an area of interest that includes and extends the C3 orebody (Figure 10) and high resolution TDEM inversions,

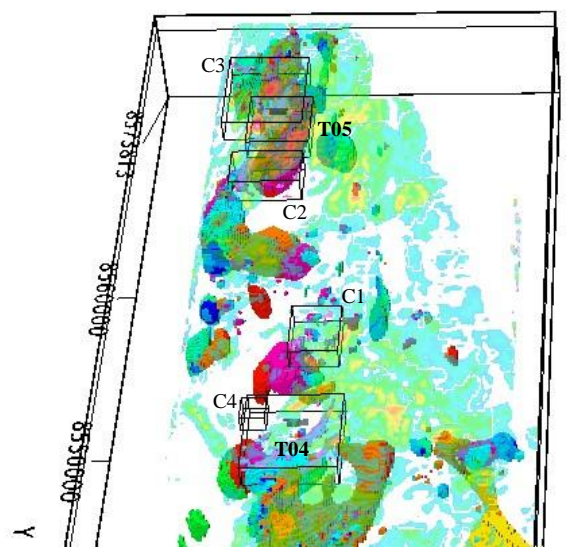

Figure 10 - SOM MVI classes, Conductivity regional inversion, high resolution inversions for orebodies $\mathrm{C} 1-\mathrm{C} 4$ and T04 and T05 clipped at $0.02 \mathrm{~S} / \mathrm{m}$.

Combining the inversion from the T05 target with the previously investigated gives a better delineation of the extension of the C3 and C2 orebody and the T04 target shows a conductive extensive body to be further investigated (Figure 11).

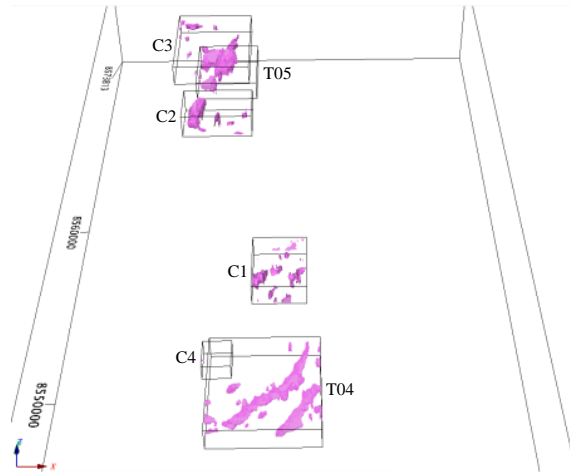

Figure 11 - High resolution inversions for orebodies $\mathrm{C} 1-\mathrm{C} 4$, T04 and T05 clipped at $0.02 \mathrm{~S} / \mathrm{m}$.

\section{Conclusions}

With the integration of MVI, SOM and TDEM inversion of magnetic and TEM data in the Palmeirópolis Project it was possible to validate the previous results from CPRM studies over 3 orebodies: C1, C2 and C3, have a better understanding of the $\mathrm{C} 4$ orebody and provide a workflow to propose additional targets to be further investigated.

Using this workflow, we have proposed and modelled with high resolution the EM data for two targets, extending the C3 orebody an identifying a new one.

\section{Acknowledgments}

The authors would like to thank CPRM for the partnership and for providing the data and reports that were used in this work.

\section{References}

Aisengart, T., Ando, J. L., Batista, L., Ferreira, L.C., 2018. Técnica de self-organizing maps (SOM) aplicada aos modelos regionais de densidade e vetor de magnetização (MVI) da provincia mineral de Carajás. $49^{\circ}$ Congresso Brasileiro de Geologia, Rio de Janeiro, Brasil.

Araújo, S. M.; Fawcett, J.J.; Scott, S.D. 1995. Metamorphism of hydrothermally altered rocks in a volcanogenic massive sulfide deposit: The Palmeirópolis, Brazil, example. Revista Brasileira de Geociências, São Paulo, v.25, n.3, p.173-184.

Carneiro, C.C.; Fraser, S.J; Crósta, A.P.; Silva, A.M. and Barros, C.E.de M. 2012. Semiautomated geologic mapping using self-organizing maps and airborne geophysics in the Brazilian Amazon. In:Geophysics, 77(4),p. K17-K24.

Couto Jr., M. A.; Wosniak, R.; Marques, E. D.; Duque, T. R. F.; Carvalho, M. T. N. 2017. VTEM and Aeromagnetic Data Modeling Applied to $\mathrm{Cu}, \mathrm{Zn}$ and $\mathrm{Pb}$ Prospection in Palmeirópolis Project, TO, Brazil. 15th International Congress of Brazilian Geophysical Society, SBGf, Rio de Janeiro, RJ, Brazil.

Cracknell, M.J. \& Reading, A.M., 2014. Unsupervised clustering of continental-scale geophysical and 
geochemical data using Self-Organising Maps. Third Australian Regolith Geoscientists Association Conference. Perth, Australia.

Ellis, R. 1998. Inversion of airborne electromagnetic data. Exploration Geophysics v.29, n.2, p121-127

Ellis, R. G. , de Wet, B., MacLeod, I. N. (2012), Inversion of magnetic data for remanent and induced sources. ASEG Extended Abstracts 2012, 1-4

Oliveira, W. B. 2000. Zinco, chumbo e cobre de Palmeirópolis, Estado do Tocantins. Goiânia: CPRM, 19p. (Informe de Recursos Minerais. Série Oportunidades Minerais. Exame Atualizado de Projeto, 10).

VOTORANTIM. 2008. Interpretação de Dados Eletromagnéticos, Magnéticos e Radiométricos Aéreos Sobre o Projeto Palmeirópolis, TO. Relatório Técnico. 